\title{
Venezuela: Autocratic Consolidation and Splintered ECONOMIC LIBERALIZATION*
}

\author{
Venezuela: consolidación autocrática y liberalización económica \\ fragmentada
}

\author{
ANTULIO ROSALES \\ University of New Brunswick, Canada
}

\author{
MARYHEN JIMÉNEZ \\ University of Oxford, United Kingdom
}

\begin{abstract}
In 2020, Venezuela has gone through a process of autocratic consolidation. This consolidation has taken place amid substantial economic reforms that have allowed the government of Nicolás Maduro survive sustained international and domestic pressure. In this article, we analyze this process of autocratic consolidation. We explain how, by focusing on the establishment of an "interim-government" in 2019, the Venezuelan opposition has been unable to coordinate an inclusive strategy to successfully bring about a democratic breakthrough and instead became further divided. We address the economic transformations witnessed in the country as policies of fragmented liberalization through opaque privatizations and an uneven multi-currency system, which have resulted from a deep recession, the collapse of the oil economy and sanctions. Finally, we discuss the implications of these political and economic processes for the social fabric of the country. We highlight that despite the government's attempts at criminalizing autonomous activism, the relative strengths of civil society allowed the survival of minimal democratic spaces that have spurred dialogue and resistance.
\end{abstract}

Keywords: autocracy, Nicolás Maduro, opposition, liberalization, Venezuela.

\begin{abstract}
RESUMEN
En 2020, Venezuela pasó por un proceso de consolidación autocrática. Esta consolidación ha ocurrido en medio de reformas económicas sustanciales que han permitido al gobierno de Nicolás Maduro subsistir a la presión nacional e internacional. En este artículo analizamos el proceso de consolidación autocrática que se ha concretado en el último año. Explicamos como, al enfocarse en el establecimiento de un gobierno interino, la oposición venezolana fue incapaz de coordinar una estrategia inclusiva para desencadenar una transición exitosa a la democracia y en cambio se dividió aún más. Analizamos las transformaciones económicas que ha vivido el país producto de políticas de liberalización fragmentada, a través de
\end{abstract}

We would like to thank the Editor of the Revista de Ciencia Politica and three anonymous reviewers for their helpful feedback. A version of this paper was presented in the V Jornadas LASA-Venezuela held in June 2021. We thank the co-panelists and participants for an enriching conversation. We want to thank the members of the group Venezuela Red: grupo de estudios interdisciplinarios, in which we take part and have also shared some of these ideas.

DOI: $10.4067 /$ S0718-090X2021005000113 
privatizaciones opacas y un sistema multi-moneda, que han sido resultado de una profunda recesión, el colapso de la economía petrolera y sanciones. Finalmente, discutimos las implicancias de estos procesos políticos y económicos para la base social del país. Resaltamos que, a pesar de los intentos de criminalizar el activismo social autónomo, la relativa fuerza de la sociedad civil ha permitido la subsistencia de espacios democráticos mínimos que han facilitado diálogo y resistencia.

Palabras clave: autocracia, Nicolás Maduro, oposición, liberalización, Venezuela.

\section{INTRODUCTION}

Venezuela is a paradigmatic case of autocratization by elections (Corrales 2020; Marsteintredet 2020). Since Hugo Chávez's first electoral success in 1998 and subsequently under Nicolás Maduro's rule, the country gradually moved from being a delegative democracy, to being a hybrid regime and finally an authoritarian regime as of 2016 (Jiménez 2021). Elections have not been competitive at least since the legislative elections of 2015; opposition parties have been co-opted, banned or hijacked by state institutions; key opposition figures have been jailed, sanctioned, or pushed into exile; civil society members, journalists and media outlets continue to be harassed and persecuted, while the population's social and economic demands are rarely met or outright dismissed. Crucially, in 2016, the regime of Nicolás Maduro nullified the National Assembly's competences and blocked a drive to organize a recall referendum, at which point the government managed to overturn the results of an election and stood in the way of a democratic transition (Marsteintredet 2020). During the last two decades, most analyses centered around questions on the quality and fate of Venezuela's democracy. However, now that democracy has dissipated and that the ruling elite in the country has successfully retained power, we contend that Venezuela has gone through a process of authoritarian consolidation, despite the challenges imposed by domestic and international forces to seek regime change.

In 2019, the Venezuelan opposition decided to seek regime change through the establishment of an "interim-government" (IG) led by Juan Guaidó, whose national legitimacy derived from the 2015 legislative election (Boersner 2020). Yet, despite having achieved a formidable majority in the National Assembly (NA) that garnered significant international support for the IG in the wake of a non-competitive presidential election in 2018, the opposition, instead of delivering on its promise to oust the autocrat, began to crumble and Nicolás Maduro has now consolidated his grip on power. Not only has he managed to sustain elite cohesion, replace the previous opposition-controlled NA with government loyalists in non-competitive elections held in December 2020, he has also initiated a transformation of the country's economy, from a highly centralized and statist system, to one with pockets of liberalized and deregulated markets. All these political and economic processes led by Maduro have taken place amid a transnational dynamic of hostility, marked by sanctions and diplomatic 
efforts to encourage a change in regime type, and geopolitical (re)alignment. Now, what explains this authoritarian consolidation in Venezuela?

In this article, we put forward two interrelated arguments. Firstly, misleading opposition strategies have contributed to its decreasing effectiveness to challenge authoritarian rule and as a result, Maduro has intensified his ties to non-democratic regimes and implemented a series of economic liberalization reforms to guarantee regime survival. By focusing on the establishment of an IG, the Venezuelan opposition was unable to coordinate an inclusive strategy to successfully bring about a democratic breakthrough and instead became further divided. The lack of clear decision-making rules and conflict resolution mechanisms on an elite-level, on the one hand, and having neglected strong linkages to the population, on the other, contributed to the opposition's internal weakening despite its international support. Secondly, we address the economic transformations witnessed in the country, which have resulted from a deep recession and the collapse of the oil economy. We argue that both processes, of autocratic consolidation and economic transformation, emerged as a consequence of domestic and transnational dynamics and alliances, where the Maduro regime took advantage of its control over the military and managed to wedge divisions among the national and international actors that oppose it. Finally, we discuss the implications of these political and economic processes for the social fabric of the country in the context of the COVID-19 pandemic. We highlight that despite the government's attempts at criminalizing autonomous activism and further marginalizing social organizing, the relative strengths of civil society allowed the survival of minimal democratic spaces and supported humanitarian actions that mitigated the effects of the social and public health crises.

This article analyzes the main processes of political and economic changes occurred in Venezuela during 2020. It also provides insights to processes that date back to the origins of the Venezuelan crisis as well as different bodies of literature. We draw on primary research based on media and institutional reports, as well as secondary research based on comparative politics and political economy literatures. We build upon debates around democratic backsliding and comparative economic reforms in authoritarian contexts to characterize the Venezuelan process of autocratic consolidation with splintered economic liberalization. Moreover, we reflect on the intended and unintended effects of transnational processes and alliances as well as the repercussions of global transformations amid a once in a century pandemic that brought the world to a halt.

\section{THE DECREASING EFFICIENCY OF THE VENEZUELAN OPPOSITION}

Hugo Chávez and Nicolás Maduro always faced significant opposition to their rule. Either through mass protests, strikes, a coup attempt, electoral participation or boycott, international pressure, or the establishment of the IG in 2019, partisan and nonpartisan actors pushed back against the so-called Bolivarian 
Revolution, so far without success in their attempt at taking power. While their strategies have varied from insurrectional to electoral paths, and the nature of the Bolivarian regime also changed from a formal democracy to an authoritarian regime, the Venezuelan opposition has recently been intensively pushing for a transition to liberal democratic rule through the Guaidó-led IG (Alfaro Pareja 2020; Boersner 2020). The Venezuelan partisan opposition has at times been close to crafting a transition to democracy, mostly so, when they coordinated their actions to challenge the ever more authoritarian government collectively. Comparative work on opposition strategies and behaviour in non-democratic contexts in fact argues that coordination is important when seeking liberalization and/or regime change (Bunce \& Wolchik 2011; Donno 2013; Howard \& Roessler 2006; Ong 2016; Selçuk \& Hekimci 2020). This is so because coordination helps present a viable and credible opposition, aggregate vote-share, reduce incentives for regime cooptation and repression as well as pool resources to outsmart a generally more powerful and non-democratic player. Yet, oppositions can coordinate in different ways, either formal or informal, and the way they coordinate will affect their capacity to challenge an authoritarian government differently (Jiménez 2021).

According to Jiménez (2021) the opposition in Venezuela has coordinated both formally, that is, through a coalition with clear decision-making rules and conflict resolution mechanisms, the Mesa de la Unidad Democrática (MUD) and informally, around one-off actions or loose coordination platforms, such as the Coordinadora Democrática and Frente Amplio.These types of coordination responded to different repression levels and, consequently to different opportunity structures during the Chávez and Maduro governments respectively. Low repression under Chávez and high repression under Maduro has invoked informal coordination arrangements mainly because during the former, parties were not sufficiently threatened to assume the costs of formal coordination and during the latter, personal risks and reduced probabilities of effectively contesting elections have impeded formal coordination. It was under intermediate levels of repression (2007-2015) that the opposition could coalesce under the MUD (Jiménez 2021).

The MUD allowed for a more pluralistic and methodological strategy-formation when challenging both Chávez and Maduro (Cannon 2014), whereas Frente Amplio or IG have encouraged a more top-down approach, in which the actors with larger material and non-material resources, mostly private sector and media, could impose their preferred strategies onto weaker the ones, political parties and civil society groups (García-Guadilla \& Mallen 2013; Jiménez 2021). Moreover, the MUD allowed the opposition to progressively grow electorally since 2010 and gave voters a collective and centrist project that could opt for in a highly polarized environment (Aveledo 2021).

This distinction helps us understand opposition dilemmas and existing cleavages in non-democratic contexts. The Venezuelan opposition has been (naturally) divided along ideological lines (Trak 2020), but also along strategic 
ones: while some groups have considered the gradual and electoral route a more successful road towards democratization, others have consistently believed in a contentious and internationally-backed or even interventionist way out of the crisis. These cleavages, but also individual aspirations to lead the opposition movement, were somewhat contained under the umbrella organization MUD, which functioned between 2009 and 2016 an Executive Secretariat, advisor teams, statutes, and draft programs (Jiménez 2021). After the demise of the MUD, which paradoxically occurred upon achieving a supermajority in the NA, these pre-existing cleavages, ambitions, and personal rivalries flourished once again, and the opposition did not elaborate any formal coordination agreement to guide and structure their strategy-formation processes. The MUD was effectively replaced by the inner-workings of the NA between 2016 and 2019, an institution that represented the most important parties of the opposition.

The absence of an umbrella structure outside the NA meant that decision-making was largely influenced by leaders and parties' strategic vision. Given that opposition parties agreed on rotating the presidency of the NA, each year between 2015-2020, each of these parties defined the actions and discourse to be implemented during a given year. Lacking collective strategy-formation, parties began to put forward their own preferences and ambitions to capitalize on a transition longed for. Over time, lack of formal coordination contributed to the gradual weakness of the Venezuelan opposition.

As Juan Guaidó swore in as president of the NA and "interim-president" he inherited pre-existing internal schisms and divergent strategic preferences. While during 2019 he counted on significant international support that allowed him and his team to navigate these challenges, in 2020 Guaidó's popularity began to fall. According to recent Datanalisis polls, approval ratings fell from $61 \%$ in February 2019 to 27\% in September 2020 (Tomillo 2020) and as of March 2021 in a hypothetical presidential election only $11,4 \%$ would vote for Guaidó (Efecto Cocuyo 2021b). What explains this demise?

Guaidó's fall, of course, cannot be attributed to only one variable. Harsh persecution and repression towards close figures and family members, as well as limited access to funds, media, in a context of humanitarian emergency, institutional decay and state fragility impose significant barriers to a democratization process. Maduro's government and ruling coalition controls all state institutions, including the National Electoral Council (CNE), the judiciary (TSJ), the military (FANB). Since January 2021, it also controls the NA, which resulted from an unfair and skewed electoral process in December 2020. In line with previous efforts, the government has also continued to debilitate the opposition coalition around Guaidó through targeted repression, but also cooptation attempts. The cases of José Brito, former Voluntad Popular (VP) member, and Luis Parra, former Primero Justicia (PJ) member, are amongst the most visible ones. These politicians challenged Guaidó's legitimacy in January 2020 and supported Maduro's move against the opposition-controlled NA (BBC 2021), however 
unsuccessfully. The emergence of so-called 'alacranes' ('scorpions' willing to betray their parties and work with the government) within the opposition also explains how the Maduro regime has used sanctions in its favor. This group of opposition members of parliament brought cases against their party leadership before the TSJ and was also part of broader lobby strategies by government cronies who sought sanction relief in Colombia and the United States (Deniz 2020). Through different corruption networks as strategies to bypass sanctions, the government has managed to foster divisions in the opposition (Deniz 2020).

Maduro and the Partido Socialista Unido de Venezuela's (PSUV) ambition and steps to achieve hegemonic power in Venezuela are evident. Yet, a crucial question remains whether oppositions can -willingly or unwillingly- contribute to the process of democratic erosion. Gamboa's work (2017) on Colombia and Venezuela argues that they can. When oppositions pursue radical and extra-institutional strategies, they can lose institutional resources, help autocrats advance their non-democratic aspirations and more radical reforms. Gamboa focuses on the first years of Chavismo and Uribismo, but her argument about the importance of how oppositions challenge presidents with hegemonic aspirations and authoritarian ambitions might travel across time and regime type. We argue that a series of choices made by opposition leading figures could have decreased the probabilities of change, thereby allowing Maduro to consolidate his grip on power. This is not to say that oppositions are responsible for autocratization. Instead, we aim to advance previous scholarship on the types of strategies oppositions can use to prevent further autocratization and/ or successfully pursue regime change.

\section{Missed opportunities for broad-based socio-political coordination}

Scholars have warned that one of Guaidó's major mistakes has been to "delegate" domestic strategy-formation to international actors, mostly the US under the Trump administration hoping that a harsh discourse against socialism, sanctions, indictments or (un)credible threats of the use of force would cause disagreements and splits within the ruling coalition. Under Mike Pompeo and John Bolton's leadership since 2018, Trump's approach towards Venezuela became less multilateral, increasingly polarizing and unfocused (Ramsey \& Smilde 2020; Puerta 2021), leaving the Venezuelan opposition in a less favorable position to negotiate with the Maduro regime. A closely linked political and strategic error ever has been the weakening of the domestic democratic coalition. This has taken place in several ways.

First, by 2016, opposition parties dismantled the MUD, a body that had facilitated collective strategizing and political unity. This move weakened the opposition until today because: i) it erased a space for clear decision-making and conflict resolution, causing fragmentation along strategy-formation; ii) it removed a centrist collective platform with the capacity to attract a larger 
vote share of the population, including "dissident chavistas", and which communicated a viable alternative to the electorate; and iii) it facilitated regime cooptation of minor groups. Guaidó's IG has not been able to recreate similar collective decision-mechanisms and failed to reconcile the ever more divided opposition camp. Instead, the IG became a platform largely influenced by VP and partly PJ associates. Throughout 2020, divisions along minimalist factions, moderates, and maximalists who all have different notions of how to challenge the incumbent regime became ever more evident (PolitiKa UCAB 2020). Leaders such as María Corina Machado, Antonio Ledezma and Diego Arria, who promote the idea of foreign-imposed regime change through an intervention, have openly criticized and distanced themselves from Guaidó, who in their view, has failed to implement the Inter-American Treaty of Reciprocal Assistance signed in 1947 (TIAR) and build a multilateral coalition to intervene the country. The minimalist coalition embodied by the Roundtable for National Dialogue, which includes former presidential candidate Henri Falcón (Avanzada Progresista), former UNT deputy Timoteo Zambrano (now Cambiemos), members of the left-leaning MAS, among others, have advocated for an electoral route in spite of there not being sufficient electoral conditions for a meaningful participation (Cañizález 2020). This small group of dissidents favor unconditional, open-ended dialogue with the government, while blaming Guaidó for not achieving his goals. Their position has generated suspicion from other opposition parties. Finally, leaders like Henrique Capriles have also openly withdrawn their support from Guaidó who they accuse of living a "fantasy" with the IG (El Nacional 2020). Although most opposition figures sustain that "unity" is necessary, it appears that the IG has been largely influenced by VP and its views of regime collapse through sanctions and pressure (Crónica Uno 2020; Sucre 2021), which in turn, inhibited a broader coordination process between partisan actors who vary in terms of ideology, access to resources, international linkages and strategic preferences. Guaidó himself, for example, only stepped down as a VP party member in January 2020, almost a year after the beginning of the IG (CCN 2020).

Secondly, there have been significant strategic inconsistencies within the Guaidó-led opposition up to the point where it is not clear how exactly the opposition he represents plans to oust Maduro. In 2019, Guaidó proposed a three-step guideline towards a transition -cessation of usurpation, transitional government, free elections- which did not prosper (Boersner 2020). Although participating in elections as a means to pressure the government and pursuing an integral negotiation with the government had previously been elements of a way out of the crisis (i.e. Norway-led negotiation), through most of 2020, his coalition held onto this scheme and pursued a "maximum pressure" strategy hoping that it would result in a collapse of the Maduro regime, either because military officers or regime insiders would turn on him, due to the sanctions or because there would be a social rebellion triggered by the humanitarian and economic crisis (ICG 2020; Jiménez \& Rosales 2020). In fact, Guaidó's coalition 
advocated for more sanctions, the application of TIAR and/or invoking the principles of Responsibility to Protect (R2P), even though international actors had long announced that a military intervention in Venezuela was off the table. The preference for a clean-cut transition within some sectors of the opposition was further evidenced by the "Operation Gedeón" in May 2020, a failed attempt by a small group of hired soldiers to oust Maduro. Though Guaidó denies having participated in this operation, one of his advisors and former member of his interim-government, Juan Rendón, acknowledged having signed a preliminary agreement with Jordan Goudreau's Silvercorp, the firm that sought to depose Maduro (Rodríguez Rosas 2020). Guaidó and Leopoldo López's apparent preference for a transition through a "rupture" has prevented the opposition to focus on strengthening their internal capacities to seek change (Prieto 2020; Leguízamo 2021). Thus, in addition to the lacking coordination on an elite-level, during 2020, the opposition failed to take the electoral and negotiated route seriously, inducing them to abandon the construction of a much-needed catchall grass-roots social movement of resistance.

Finally, the IG has faced the limitations of not being able to govern, while being recognized as head of state by dozens of foreign countries. It controls some important foreign assets, but internally it has no power over state institutions, bureaucracy, or security forces (Tal Cual 2020). This is not a minor point considering that the Venezuelan population needs urgent responses to their daily problems. Having an IG that cannot deliver public goods or its promises to oust Maduro might have added to Guaidó's declining support. In addition, having been involved in corruption scandals that, while they do not mirror the government's large scale and deeply ingrained graft, weakens its own capacity to represent a drastically different alternative to the authoritarian ruler. In their work on Eastern European countries, Bunce and Wolchick (2011) argue that being a viable opposition is crucial to attract wide popular support. Being involved in alleged mismanagement of funds and not having serious transparency and accountability mechanisms (Efecto Cocuyo 2020; 2021a) in a context of humanitarian emergency and governmental mass corruption affects the opposition's credibility and capacity to represent a viable option to Venezuelans. Internal disagreements within Guaidó's IG must have been quite significant for one of his closest allies, Primero Justicia, and his foreign minister, Julio Borges, to publicly demand a scrutiny of how funds had been used (Borges 2021). Thus, in addition to the above-mentioned points, Guaidó's discontinuous commitment to core democratic principles have further damaged the opposition's public image.

The autocratic consolidation of Maduro's regime has been catalyzed by its capacity to induce the atomization of the opposition. Moreover, the government has decided to carry out crucial economic reforms without risking its grip on power. In fact, these reforms have been a central component in its consolidation. In the next section we discuss how the government approached these reforms, rewarding specific economic groups and leveraging foreign alliances in order to bypass sanctions from the US. 


\section{SPLINTERED LIBERALIZATION AND ECONOMIC REFORM}

Analyzing the Venezuelan crisis from an economic and social perspective is remarkably challenging because the government has refused to publish official data on key indicators. There is a variety of estimates on the extent of the economy's contraction and the decline in income per capita as well as how many migrants have left in recent years. Scholarly analyses have relied increasingly on alternative studies by universities, such as the Encuesta de Calidad de Vida (UCAB 2020), and data projections from multilateral organizations. In this context, there is a wealth of scholarship that has explained the evolution of the Venezuelan economic collapse that occurred since 2013 (Pantoulas and McCoy 2019; Puente Camba and Rodríguez 2020; Bull and Rosales 2020). A combination of mismanagement, failed economic policies, oil price collapse and US-imposed sanctions account for this decline, which at the end of 2020 reached $80 \%$ of the Gross Domestic Product (GDP). The collapse of the Venezuelan economy is connected to a drastic deterioration of the oil industry's capacity to maintain production, amid macroeconomic distortions fueled by an over decade long anachronistic currency control. According to the Organization of Petroleum Exporting Countries (OPEC), Venezuela produced on average 557,000 bpd in 2020 with monthly lows below 400,000 barrels. Lack of investments in oil fields, together with difficulties acquiring loans from 2015 onward set the industry in an unprecedented crisis (Monaldi et al 2020). In turn, inorganic fiscal financing to maintain price controls and subsidies despite a decline in foreign lending and a slowdown in oil prices provoked hyperinflation and other problems such as scarcity, smuggling of basic items and fuel, among others (Balza Guanipa 2021). US-imposed sanctions aggravated an already deep crisis, first by preventing the treasury and PDVSA from renegotiating their debt in 2017 and, later, by denying the US market for Venezuela's oil in 2019 (Rodríguez 2019; Bull and Rosales 2020).

Sanctions therefore contributed to further shrinking the government's sources of income as well as international markets from traditional partners, thereby forcing changes to the country's economic policies. New studies are emerging about the government responses to this crisis and the different policy changes that have taken place as a response to sanctions (Sutherland 2019; Boersner 2020). In the past few years, the Venezuelan government has undertaken stark and pragmatic economic reforms that have transformed some of the pillars of the Bolivarian economic model, which was based on strong state controls and interventions in the economy with redistributive goals. The changes have been unintended in two ways. First, the government's decisions to change some of the pillars of Bolivarian socialism come out of a forced reality, due to the drying up of revenue sources. Even at the outset of the crisis, the government tended to double down on the model rather than reform it, so the more recent and rather arbitrary change of pace is born out of necessity rather than conviction with the closing of trade avenues and foreign financing. Secondly, they are unintended also in the sense that the US sanctions policy sought to force a break 
down in the Maduro regime and were not explicitly intended to force economic liberalization. In this case, a fragmented liberalization is not accompanied by conditional loans or any multilateral support which continues to be pending a political resolution.

Several reforms have been carried out in the county's economy. These reforms are not to be confused with orthodox market, or so-called 'neoliberal' policies, common to the 1980s and 1990s controversial Washington consensus. The commonly known neoliberal policies of the 1990s included macroeconomic stability packages to reduce fiscal deficits via austerity measures and decreasing the role of the state in the economy through the privatization of state-owned enterprises and utilities (Stallings and Peres 2011). Monetary policies geared to control inflation were pursued by largely autonomous central banks, while trade liberalization and de-regulation became the norm under the guise of multilateral principles.

In the current context in Venezuela the policies of fragmented liberalization have been varied, often opening space for liberalized markets with continued presence of state action. First, the liberalization of currency markets has been accompanied by other currency restrictions, forcing citizens to use dollars and other means to carry out common transactions. These policies have been carried out by a government-controlled central bank. Second, the state has single-handedly designed property transfers with little to no transparency, assigning who the winners of privatization policies are. Third, the government has carried out these policies under the veil of secrecy, lacking any meaningful oversight from deliberative bodies. Lastly, other possible reforms pertaining to the fiscal regime and budget have not been addressed, while a renegotiation of debts and new loans are unattainable unless sanctions are lifted. And yet, foreign allies, such as China has been unwilling to serve the lending purpose it once had (Rosales 2018), even when it is not subject to the purview of US financial restrictions. Venezuela has relied on other partners, increasingly Russia and Turkey, to carry out key exchanges (Cardozo Uzcátegui and Mijares 2020).

This splintered liberalization translated into the strengthening of a new economic elite, encouraged and protected by the government, as well as the re-alignment of geopolitical interests with new and existing partnerships. Following an analysis of these reforms, it would be wrong to assume that the Venezuelan regime is deploying a Chinese-style of market socialism, but rather it is more closely linked to a Russian-style transition. As Rutland explains in the case of Russia "while prices were freed and international trade and currency flows opened up, an insider-dominated privatization process left the Russian economy in the hands of a narrow circle of oligarchs" $(2013,232)$. The Venezuelan regime is transitioning to a patrimonial capitalism that resembles some features of the Russian model, where formal and informal rules collide or overlap, economic elites and political ones seem to be converging and political power is not bound by institutions and accountability (Robinson 2011). While the private sector may be witnessing spaces for growth, it is also beholden to 
the informal rules of state control (Vasileva 2018), with particularly pernicious consequences for smaller businesses and those with less access to import lines, dollar-denominated markets, and weaker connections to power. In this splintered liberalization, the armed forces have seen new opportunities emerge for informal revenues through the opening of new market niches and through a series of control mechanisms under their command.

\section{An uneven and unequal multi-currency system}

Among the most important recent changes, there has been a consolidation of a liberalization process in the currency market, coupled with a stringent policy of monetary control via high bank reserve requirements (Sutherland 2019; Bull and Rosales 2020). The government allowed the circulation and exchange of US dollars in the economy and, despite some concrete disparities, it has also brought the official exchange rate on par with the market rate, something that had not happened since 2003 when the government imposed currency exchange controls. This splintered liberalization of the currency market has translated into an informal dollarization (Boersner 2020, 346). Nicolás Maduro lauded this dollarization as an "escape valve" to the economic pressures the country has experienced. Balza Guanipa (2021) argues, instead, that in Venezuela there is an 'incomplete multi-currency system', where the national legal tender, Bolívar, coexists with other media of exchange. In this context, the dollar has progressively become dominant, but in border areas, the Colombian peso and Brazilian real have a significant presence, while the euro, gold and other forms of exchange coexist. Various studies suggest that more than half of transactions are carried out in dollars, while online payment mechanisms have become common, such as the use of electronic transfers via Zelle and cryptocurrency operations (Rosati, Vásquez, Surane 2020; Salmeron 2020). The use of US dollars creates considerable complications for customers, as there is lack of exact change and the quality of notes is declining rapidly. This kind of disorganized dollarization also contributes to opacity, as the dollar-denominated economy is hardly quantified.

In addition, an informal dollarization translates into inequality and unevenness. In terms of inequality, while some Venezuelans have access to dollars either in cash or online through contacts and relatives abroad, many do not and depend exclusively on public sector employment and government transfers and food rations, both of which have become sparser. This inequality has especially affected the provision of public services. Public universities have been hollowed out due to poverty wages of academic staff who have abandoned their positions to either migrate or find work remunerated in hard currency (Acosta 2018). A similar situation occurred in the health care system, where private practices have become dollarized while the public sector is ever more fragile. 
Informal dollarization also translates into unevenness in the way transactions occur, as well as geographical and even sectoral unevenness in the dollarized economy. Based on a Datanálisis poll, approximately $61 \%$ of transactions are carried out in dollars and $60 \%$ of those are done in cash, while some $25 \%$ are done through Zelle and 14\% through foreign-denominated cards. This means that around $40 \%$ of those transactions never really touch the Venezuelan economy, while $60 \%$ are done in cash, with the vast majority being outside of the purview of official accounting, and thus unaccounted for tax purposes (Salmeron 2020). Other pollsters, such as Econalítica, estimate that while the average for transactions in dollars in Caracas surrounds 60\%, the proportion is much larger in large cities closer to the Colombian border, such as Maracaibo and San Cristóbal with over 90\% of transactions occurring in dollars (Figueroa 2020). Meanwhile, more distant states to international borders or commercial hubs have less access to US dollars.

Venezuelans require basic technological infrastructure to carry out transactions, so the failure of internet and electricity provision - a common occurrence in large parts of the country- affects electronic payments in hard currency, and in Bolívares. The drastic restrictions of cash withdrawals in the banking system and the increasing credit crunch make it exceedingly difficult for Venezuelans to hold cash in Bolívares for even simple transactions such as public transport payments. Hence, card payments and e-transfers are crucial for the Bolívar-denominated economy as well. In a discursive turn, the government of Nicolás Maduro has suggested that the Venezuelan economy will transition to a 'fully digital economy' with physical money giving way to online media of exchange (Yapur 2021). While this is partly a de facto reality, it is far from an idealized futuristic and a technologically-driven development, but forced out of necessity (Rosati, Vásquez, Surane 2020). It is ultimately a consequence of state failure to carry out sorely needed reforms to solve hyperinflation and secure a functional monetary system.

\section{Stealth privatizations and property concessions}

In line with the notion of arbitrary deregulation, the Maduro government has carried out a massive campaign of stealth privatizations. A comprehensive picture of these measures is lacking and that is precisely the intent of the policy. The government has been carrying out sales of state-owned enterprises, some of which have been returned to previous owners, while others have been sold to new investors (Seijas Meneses 2021). Another category refers to properties that have been given in concession, so there is no actual transfer of assets but a right to carry out production or extraction, as in the case of mines or oil camps. The government has also established alliances with foreign investors, who are willing to bypass sanctions to set up businesses in Venezuela, fueling new imports (Sutherland 2019). The retail sector has benefitted especially from 
investments coming from allied countries such as Syria, Iran and Turkey. The expansion of dollar-denominated 'bodegones' or convenience (luxury) stores of varied size began a trend that now includes larger supermarket chains (Seijas Meneces 2021).

In October 2020, the National Constituent Assembly (NCA), a supra-constitutional body created by the Maduro regime to bypass the opposition-led NA (2015-2020), approved the "anti-blockade law", as a measure to, in theory, counter the effects of sanctions in the economy. This law came to formalize some of the changes that had already been taking place and to give them a mantle of legality. The law allows the government to approve privatizations of state-owned assets, including changing the composition of joint-ventures in the oil industry. This last disposition is perhaps the most significant one because transforming ownership structure of joint-ventures is a sensitive issue in Venezuela's oil policy that would normally require parliamentary approval. In governance terms, the law gives the government unchecked license to sell assets and disregard constitutional mandates through protections of confidentiality and secrecy. These privatization measures are thus protected as state secrets.

The excuse for this law is to protect and ensure "the effectiveness of measures taken by the Venezuelan government" against the so-called international coercive, unilateral, restrictive and punitive measures (ANC 2020). The US economic sanctions were used to justify the implementation of drastic economic changes that siphon resources to new elites, while the government secured its own power. The most important takeaway of this law is that the government took advantage of sanctions to transfer assets away from the state and into private hands in absence of any meaningful debate and external control. While the ANC was dismantled at the end of 2020 with the election of a new NA with overwhelming ruling party majority, the "anti-blockade law" in fact extends the life of supra-constitutional powers to the government as it can arbitrarily pass economic reforms without oversight even from its tailored-loyal parliament.

No other sector is of greater importance in the government's search for investors than the oil industry. As mentioned, the government's goal with the anti-blockade law is to attract private capital and secure secrecy in its transfers of assets to investors. The Maduro regime has attempted changes in the oil industry for some time before the approval of the law, including increasing control capacity to partners in the joint-ventures. While the government remains vocal about its desire to offer improved conditions for willing investors, there is little to no interest in these deals. The reasons are varied but the changing conditions and tenuous legal structure is a deterrent for large oil firms. In addition, the prospects of a declining global oil market and slowed down global consumption during a pandemic makes long-investments in a complicated environment such as Venezuela's unlikely. 
Despite the inability to find new investments in the fields, the Maduro regime has allied more closely with emerging powers that are willing to bypass US financial and trade sanctions to sell the meagre production that continues to flow out of Venezuelan oil fields. The government was willing to sell its oil at greater discounts in 2020, even at a time of already low oil prices. PDVSA used partners from the United Arab Emirates and Russia to transport its oil and sell it in international markets, many of these shipments are not registered, as companies are trying to evade US authorities (Reuters 2020). In the last quarter of 2020, Venezuela's oil exports increased thanks to these maneuvers, allowing the country to sell crude to China and other Asian partners. The relationship with both Russia and Iran also suggests a potential global authoritarian learning process whereby autocratic regimes have supported each other in the context of US sanctions, while taking advantage of Venezuela's subsidiary position to make profitable businesses with gold payments.

These oil trade moves and international alliances impact violent forms of dispossession in the country through gold mining, which is associated with criminal and environmentally disastrous activity in the southeastern part of Venezuela, in the Orinoco Mining Arc (International Crisis Group 2019). The lack of international credit to Venezuelan officials has pushed the government to use gold ingots as forms of payment for transnational transactions. The military has been associated with criminal organizations that have taken mining territories and subjected local miners (Rosales 2019). Iranian excess gasoline supply due to the COVID-19 slow-down has been sold to Venezuela to supply the domestic market, which faced dramatic shortages in 2020. These fuel sales have been done mostly through gold payments, while the Venezuelan government has used the fuel shortage to make a domestic market price overhaul, bringing the price of gasoline almost on par to international levels. These transactions require collaboration from financial institutions that facilitate triangulation in payments and allow government officials, private dignitaries or name men to operate as intermediaries.

In sum, the deepening of Venezuela's economic crisis and the aggravating sanctions imposed by the US forced unintended changes in the economic direction of the country. These changes are not directed toward a form of Chinese-style "market-socialism" but rather a fragmented liberalization, with arbitrary rules that allow for discretionary governmental action and the transfer of sources of rent and property to allies of the regime. They further re-align the Venezuelan economy to existing and new international partners that are willing to bypass sanctions and allow for the emergence of global authoritarian solidarity and an increasing learning process around "off-the-radar" trade and investment flows. In other words, misguided international pressure has strengthened economic relations with non-democratic regimes, while also allowing Maduro to implement otherwise ideologically distant reforms that are aimed at maintaining authoritarian rule rather than weakening it. 


\section{CIVIL SOCIETY AND THE PROMISE OF DEMOCRATIC PROTECTION}

Despite the process of autocratic consolidation through the collapse of the organized opposition and changes in the economy that have strengthened Maduro's position, there remains space for civil society articulation and civic action. To be clear, the conditions for autonomous civil society action are dire. Venezuela's poverty rate surpasses $90 \%$ of households according to the Calidad de Vida poll carried out by Venezuelan universities (UCAB 2020). In addition, civil society organizing is increasingly criminalized and the country faced the COVID-19 pandemic virtually unprotected, with a health care system in shambles and little to no government support to compensate businesses and workers in the context lockdowns and stay at home orders. As in other authoritarian countries, Maduro has also used the COVID-19 pandemic to increase surveillance, persecution and societal control (Ávila 2020; Gebrekidan 2020). As a result, the opposition's capacity to convene protests, mobilizations or even in-person discussions and strategy meetings decreased. Further, an unexpected inflow of Venezuelan migrants returned to the country from South American neighbors in 2020, amid epidemic measures of lockdowns throughout the region. These returnees were received with suspicion by government officials who often stigmatized them as potential "biological weapons" coming to the country to purposefully spread the virus (Contrapunto 2020).

In this context, non-governmental organizations (NGOs) have been crucial in documenting and reporting human rights violations in coordination with international organizations and global non-governmental organizations. Systematic human rights violations, criminalization of dissidents, police brutality, increasing violence occurring in Venezuela's non-democratic context have been denounced by local and civil society organizations and IGOs. They have also been documented by UN bodies, such as the High Commissioner of Human Rights (OHCHR) and the UN's Independent Fact-Finding Mission, with the support of local NGOs (Amnesty International 2019a, 2019b; OHCHR 2019, 2020; FIDH \& Provea 2020; UNHRC 2020). The latter found high-rank state authorities "responsible for atrocities that they believed amounted to crimes against humanity" (Human Rights Watch 2021). As of November 2020, there were nearly 400 political prisoners and 2,800 alleged extrajudicial killings of the 18,000 since 2016 occurred in 2020 alone (Human Rights Watch 2021; Provea 2021). The fact that these denunciations have been reported through the United Nations agencies has drawn attention to crimes against humanity in Venezuela and forced at least minimal actions from the NCA-imposed Attorney General to initiate investigations of special security forces such as the FAES, even if still falling short of dismantling them as the OHCHR has recommended (OHCHR 2020). Many of these actions have been a result of civil society engagement. Despite the hostile environment and deliberate persecution by the government, human rights defenders and civil society organizations have been able to develop resilience and pressure the authoritarian regime through domestic and 
international activism. Relying on original data gathered through a survey and semi-structured interviews with human rights defenders and activists across Venezuela, a report by Jiménez and Trujillo (2021) argues that organizations have developed a series of strategies to be able to survive and operate in the ongoing non-democratic context. Among the most relevant ones they count i) learning from past practices ("institutional legacy"), ii) creating strong decentralized "resilience networks" and iii) establishing linkages with international partners to exert pressure on the state (Jiménez \& Trujillo 2021).

In fact, creating networks has been a widely used mechanism across non-partisan groups to push for change on various fronts. Different civil society groups have articulated initiatives of citizen participation and dialogue. For example, Creemos Alianzas Ciudadanas, Caracas Ciudad Plural, Diálogo Social or the newly created Foro Cívico, among many others, are spaces where members of private sector and business, academia, activists, and social movements deliberate and design collective action to help re-institutionalize the country. In the case of Foro Cívico, members belonging to this platform put forward independent candidates to the selection committee for a new electoral authority. According to their view, members do not seek to replace the partisan leadership, as it happened in 2001-2002, but instead, they hope to generate meeting points for debate and promote a political agreements, influence the public agenda on public health measures and push for changes in pressing policy issues (Moreno Torrealba 2021; WOLA 2021). In terms of humanitarian work, civil society organizations, for instance, created an independent platform to document and monitor the Complex Humanitarian Emergency affecting the country since 2016. This type of documentation work has been essential in presenting reliable evidence and information to decision-makers about the serious situation of human rights violations, needs of protection and humanitarian assistance in Venezuela (HumVenezuela 2021). Finally, regarding international and domestic activism, the pandemic and State of Emergency imposed by the Maduro government, have sparked a series of online events, discussion fora, online courses, to discuss historical and contemporary Venezuelan affairs. This appears to be an important opportunity for a much needed reflection and collective action and for bridging the gap between Venezuelans at home and abroad.

While it is too early to assess the causes and impact of this rise in civil society articulation and advocacy, we contend that the state's abandonment of social protection and public services has demanded action from other actors to fill important gaps to aid the survival of the Venezuelan population. In addition, the dire situation of universities and research institutions may be forging new spaces for experts and technical professionals to channel their expertise in needed areas through international partnerships. Lastly, the increased international attention to the Venezuelan complex humanitarian emergency has not only come from states and international organizations but also from transnational civil society organizations, which has contributed to maintaining visibility on the ongoing crisis. The remaining social organizing and activism during the 
process of autocratic consolidation has important implications, both in scholarly and policy terms. First, researchers of Venezuelan politics and Latin American studies, more generally, should pay closer attention at the resiliency and capacity of social organizing even the context of general closure of democratic spaces. In this case, further research is needed to shed light on the articulations of civil society organizations and international institutions, as well as global NGOs. Second, grassroot push back to autocratic politics can be a starting point for long term re-democratization if political leaders can feed from those actions without intending to coopt them. Issues such as social provisions during the pandemic as well as more structural legislative and rights-based demands such as women's reproductive rights, environmental protection and indigenous people's rights can be vectors of political action that help unite diverse social actors in broad democratic mobilization.

\section{CONCLUSIONS}

In this article, we have argued that during 2020 Venezuela has gone through a process of autocratic consolidation. After two years of harsh economic and diplomatic pressure embodied by a tough sanctions regime and the international recognition of the IG even after 2020, Nicolás Maduro has continued to control all institutions and his government in a stronger position than it had been since massive protests erupted in 2017. This consolidation has taken place amid substantial economic reforms that have allowed the government of Nicolás Maduro survive sustained pressure. Yet, while tamed by divisions in the opposition, Venezuela's political conflict and dreadful socio-economic crisis remain unresolved, despite of internationally supported and domestic attempts at seeking regime change through the IG.

As we have argued in this article, during 2020, Nicolás Maduro consolidated his hold onto power and increased persecution, repression and criminalization of partisan and nonpartisan dissidents. The Guaidó-led opposition incurred in significant political and strategic mistakes, which contributed to the consolidation of authoritarianism in the country. We do not contend that the opposition is responsible for increased autocratization, but argue that the strategies pursued by the IG might have affected the likelihood of regime change in several ways: i) the absence of clear decision-making rules and conflict resolution mechanisms inhibited a broad-based and inclusive coordination, which could have impeded current fragmentation, ii) largely delegating strategy-formation to international actors and hoping that a "maximum pressure" strategy would bring about regime change, kept the IG from engaging with and mobilizing Venezuelans around a sustainable route towards democratization; and iii) insisting on being an IG, when Guaidó is not able to govern or influence state behaviour, could have contributed to a lack of credibility and viability among the population. 
This process of autocratic consolidation was accompanied by a dynamic of increasing economic reforms that we labeled splintered liberalization. This form of liberalization was the unintended result of a deepening economic collapse and the effects of US-imposed financial and oil sanctions. The Maduro government embraced fragmented liberalization policies that turned the country's monetary system into a multicurrency one, where the US dollar is increasingly gaining ground. Yet, this change is uneven in the economy, and it generates inequalities among the population and business sector. In addition, the government has privatized or transferred control over state-owned assets to private business with no regard to public consultation and oversight. These policy changes amount to a substantive transformation of the political economy pillars of Bolivarian socialism that account for a potential transition to a Russia-style neo-patrimonial capitalism. Crucially, these changes have strengthened new economic elites domestically but have also deepened transnational alliances with non-traditional partners.

Lastly, during 2020, and despite all the challenges the country is going through, civil society actors have found ways to connect and resist. Several initiatives have emerged to pressure political elites to negotiate a way out of the current authoritarian consolidation. Civil society organizing and activism demonstrates some limited capacity from autonomous organizations to impact public debates and forge new spaces for democratic resistance. This illustrates that even under the direst conditions, society is resisting and in fact developing resilience. Civil society resistance has managed to develop fruitful linkages with international organizations and global NGOs. It remains to be seen to what extent the political leadership will be able to feed from these spaces of plurality and civic exercise.

\section{REFERENCES}

Acosta, Yorelis. 2018. "Soy una profesora en Venezuela". Prodavinci. Retrieved from http:// factor.prodavinci.com/profesoraenvenezuela/index.html/

Alfaro Pareja, Francisco. 2020. Archipiélagos politicos bajo la tormenta en Venezuela: Coaliciones, actores y autocratización. European Review of Latin American and Caribbean Studies (109): 21-40.

Amnesty International. 2019a. Venezuela 2019. Retrieved from: https://www.amnesty.org/ en/countries/americas/venezuela/report-venezuela/

Amnesty International. 2019b. Hunger for Justice: Crimes Against Humanity in Venezuela (AMR 53/0222/2019). Retrieved from https://www.amnesty.org/en/documents/ amr53/0222/2019/en/

Asamblea Nacional Constituyente (ANC). 2020. Ley Antibloqueo para el desarrollo nacional y la garantía de los derechos humanos. Retrieved from: https://albaciudad.org/wp-content/uploads / 2020/10/ley-antibloqueo-para-el-desarrollo-nacional-y-la-garantia-de-los-derechos-humanos.-version-definitiva-fidel-ernesto-vasquez-07.10.2020. pdf

Aveledo, Guillermo T. 2021, March 6. "Notas sobre los Partidos Políticos bajo un Sistema Autoritario: El Caso Venezolano". Prodavinci. Retrieved from: https://prodavinci.com/ notas-sobre-los-partidos-politicos-bajo-un-sistema-autoritario-el-caso-venezolano / 
Ávila, Keymer. 2020, September 21. What is deadlier in Venezuela: Its security forces or COVID-19? OpenDemocracy. Retrieved from: https://www.opendemocracy.net/en/ democraciaabierta/more-deadly-venezuela-security-forces-or-covid-19/?fbclid=IwAR1w52-dk2b79JFSoV6pQxOtNlpNgYzkO9D7K0ShyduBIyiAJYJmlD3tVv0

Balza Guanipa, Ronald. 2021, February 22. Ni dolarización ni desdolarización: sistema multimoneda en Venezuela. Prodavinci. Retrieved from: https://prodavinci.com/ni-dolarizacion-ni-desdolarizacion-sistema-multimoneda-en-venezuela/

BBC. 2021, January 5. Venezuela crisis: Maduro loyalists take control of parliament. BBC News. Retrieved from https://www.bbc.com/news/world-latin-america-55545352.

Boersner, Adriana. 2020. Venezuela 2019: a tale of two presidents. Revista de Ciencia Política 40(2): 539-565.

Borges, Julio. 2021, January 22. Es fundamental dar respuesta a cada caso que ha creado dudas en la opinión pública y dar acceso a toda la información necesaria para esclarecer de manera correcta cada uno de los eventos. Twitter. Retrieved from: https:/ /twitter. com/JulioBorges/status/1352602589494439936?s=20

Bull, Benedicte and Antulio Rosales. 2020. Into the shadows: sanctions, rentierism, and economic informalization in Venezuela. European Review of Latin American and Caribbean Studies (109): 107-133.

Bunce, Valerie and Shanon Wolchik. 2011. Defeating authoritarian leaders in postcommunist countries. Cambridge: Cambridge University Press.

Cannon, Barry. 2014. As Clear as MUD: Characteristics, Objectives, and Strategies of the Opposition in Bolivarian Venezuela. Latin American Politics and Society 56(4): 49-70.

Cañizález, Andrés. 2020, June 7. "Las tres oposiciones en Venezuela". El Estímulo. Retrieved from: https:/ /elestimulo.com/las-tres-oposiciones-en-venezuela/

Cardozo Uzcátegui, Alejandro and Víctor Mijares. 2020. The versatile amalgam: Interests and corruption in Russia-Venezuela relations. European Review of Latin American and Caribbean Studies (109): 181-202.

CCN. 2020, September 20. "Presidente (e) Guaidó reitera llamado a la unidad para enfrentar y vencer a la dictadura de Maduro". Presidencia Venezuela. Retrieved from: https:// presidenciave.com/presidencia / presidente-e-guaido-reitera-llamado-a-la-unidad-del-para-enfrentar-y-vencer-a-la-dictadura-de-maduro/

Contrapunto. 2020, May. "De "un flujo migratorio normal" a las "armas biológicas": El tratamiento del gobierno de Maduro a migrantes venezolanos". Contrapunto. Retrieved from: https://contrapunto.com/nacional/derechos-humanos/de-un-flujo-migratorio-normal-a-las-armas-biologicas-el-tratamiento-del-gobierno-de-maduro-a-migrantes-venezolanos/

Corrales, Javier. 2020. Democratic backsliding through electoral irregularities: The case of Venezuela. European Review of Latin American and Caribbean Studies (109): 41-65.

Crónica Uno. 2020, December 19. “Guillermo Tell Aveledo: Lo que hemos tenido hasta ahora es la ruta de un partido en particular". Retrieved from: https://cronica.uno/guillermo-tell-aveledo-lo-que-hemos-tenido-hasta-ahora-es-la-ruta-de-un-partido-en-particular/

Deniz, Roberto. 2020. "Siete países para siete diputados en defensa de Alex Saab". Armando. info Retrieved from: https://armando.info/siete-paises-para-siete-diputados-en-defensa-de-alex-saab/

Donno, Daniela. 2013. Elections and Democratization in Authoritarian Regimes. American Journal of Political Science 57(3): 703-716.

Efecto Cocuyo. 2020, November 7. “Finanzas dispersas: El rompecabezas del Gobierno interino". Efecto Cocuyo. Retrieved from: https:/ / efectococuyo.com/especial/finanzas-dispersas-el-rompecabezas-del-gobierno-interino/

Efecto Cocuyo. 2021a, February 1. "Defensa de activos en el exterior ha costado más de 50 millones dólares". Efecto Cocuyo. Retrieved from: https://efectococuyo.com/politi$\mathrm{ca} /$ defensa-de-activos-en-el-exterior-ha-costado-mas-de-50-millones-de-dolares-endos-anos/ 
Efecto Cocuyo. 2021b, March 10. “¿Por qué un outsider le gana en intención de votos a Maduro y a Guaidó?" Efecto Cocuyo. Retrieved from: https://efectococuyo.com/politica/ un-outsider-le-gana-en-intencion-de-votos-a-maduro-y-a-guaido-segun-encuesta /

El Nacional. 2020, July 30. "Capriles a la oposición: Gobierno vs fantasía". EL NACIONAL. Retrieved from: https://www.elnacional.com/venezuela/capriles-a-la-oposicion-gobierno-vs-fantasia-gobernar-en-internet-por-favor/

FIDH \& Provea. 2020. Venezuela's complex humanitarian emergency exacerbated by Covid-19: The international community must promote urgent humanitarian agreements that favour solutions to the food and health crisis. Retrieved from: https://provea. org/wp-content/uploads/Venezuela-English-.pdf

Figueroa, Ahiana. 2020, February 26. "Ecoanalítica: 64\% de las transacciones de compra-venta se realizan en divisas." Tal Cual. Retrieved from: https://talcualdigital.com/ecoanalitica-64-de-las-transacciones-de-compra-venta-se-realizan-en-dividas /

Gamboa, Laura. 2017. “Opposition at the Margins: Strategies against the Erosion of Democracy in Colombia and Venezuela." Comparative Politics 49(4): 457-477

García-Guadilla, María Pilar and Ana Mallen. 2013. "A rude awakening: The underside of Venezuela's civil society in the time of Hugo Chávez". Politeja 24: 41-62.

Gebrekidan, Selam. 2020, March 30. "For Autocrats, and Others, Coronavirus Is a Chance to Grab Even More Power". New York Times. Retrieved from: https://www.nytimes. com/2020/03/30/world/europe/coronavirus-governments-power.html

Howard, Mark and Philip Roessler. 2006. Liberalizing Electoral Outcomes in Competitive Authoritarian Regimes. American Journal of Political Science 50(2): 365-381.

Human Rights Watch. 2021. World Report 2021: Rights Trends in Venezuela. Retrieved from: https://www.hrw.org/world-report/2021/country-chapters/venezuela

HumVenezuela. 2021. What is HumVenezuela. Retrieved from: https:/ / humvenezuela.com/ en/about-us/

ICG. 2019. "Gold and Grief in Venezuela's Violent South (No. Latin America Report 73)" International Crisis Group. Retrieved from: https://www.crisisgroup.org/latin-america-caribbean/andes/venezuela/073-gold-and-grief-venezuelas-violent-south

ICG. 2020. "Venezuela: What Lies Ahead after Election Clinches Maduro's Clean Sweep". International Crisis Group. Retrieved from: https://www.crisisgroup.org/latin-america-caribbean/andes/venezuela/85-venezuela-what-lies-ahead-after-election-clinches-maduros-clean-sweep

Jiménez, Maryhen and Antulio Rosales. 2020, December 17. "To Boycott or not to Boycott Elections in Non-democracies - Lessons from Venezuela". Mischiefs of Faction. Retrieved from: https://www.mischiefsoffaction.com/post/to-boycott-or-not-to-boycott-elections-in-non-democracies-lessons-from-venezuela

Jiménez, Maryhen. 2021. Contesting Autocracy: Opposition Coordination and Repression in Venezuela. Political Studies. Online first.

Jiménez, Maryhen, and Eduardo Trujillo. 2021. “Developing Resilience in Authoritarian Contexts. Lessons From Venezuela in Comparative Perspective". CDH-UCAB. Retrieved from: https://drive.google.com/file/d/1KWNUcDmurWEll3hpgzmGugrQn7QDC$\mathrm{vOA} /$ view

Leguízamo, Danny. 2021, January 29. "Ricardo Sucre: El interinato nunca existió". El Cooperante. Retrieved from: https://elcooperante.com/ricardo-sucre-el-interinato-nunca-existio/

Marsteintredet, Leiv. 2020 With the cards stacked against you. Challenges to a negotiated transition to democracy in Venezuela. European Review of Latin American and Caribbean Studies (109): 87-106.

Monaldi Francisco, Igor Hernández, and José La Rosa. 2020. The Collapse of the Venezuelan Oil Industry: The Role of Above-Ground Risks Limiting FDI. Working Paper. Center for Energy Studies, Rice Institute for Public Policy. Retrieved from: https:/ / www.bakerinstitute.org/media/files/files/9ba44b2d/fdi-monaldi-venezuela_uSQ8FHh.pdf 
Moreno Torrealba, Daniela. 2021, February. Foro Cívico Nacional pretende unir a los sectores para conseguir condiciones políticas. Fedecamaras radio. Retrieved from: https:// www.fedecamarasradio.com/foro-civico-nacional-pretende-unir-a-los-sectores-para-conseguir-condiciones-politicas/

OHCHR. 2019. Report of the United Nations High Commissioner for Human Rights on the situation of human rights in the Bolivarian Republic of Venezuela (A/HRC/41/18). Retrieved from: https://www.ohchr.org/EN/Countries/LACRegion/Pages/VEReportsOHCHR. aspx

OHCHR. 2020. Report of the United Nations High Commissioner for Human Rights on the situation of human rights in the Bolivarian Republic of Venezuela (A/HRC/44/54). Retrieved from: https://www.ohchr.org/EN/HRBodies/HRC/RegularSessions/Session44/Documents/A_HRC_44_54.pdf

Ong, Elvin. 2016. Opposition Coordination in Singapore's 2015 General Elections. The Round Table 105(2): 185-194.

Pantoulas, Dimitris and Jennifer McCoy. 2019. Venezuela: an Unstable Equilibrium. Revista de Ciencia Política 39(2): 391-408.

PolitiKa UCAB. 2020, October 1. "Politólogos insisten en la revisión de estrategias y narrativas opositoras". Retrieved from: https://politikaucab.net/2020/10/01/politologos-insisten-en-la-revision-de-estrategias-y-narrativas-opositoras /

Prieto, Hugo. 2020, June 28. “Michael Penfold: La crisis exige una dosis de realismo, de aceptación y de reconexión social". Prodavinci. Retrieved from: https://prodavinci.com/ michael-penfold-la-crisis-exige-una-dosis-de-realismo-de-aceptacion-y-de-reconexion-social-3/

Provea. 2021, March 9. "Policías y militares asesinaron a 2853 personas en Venezuela durante 2020". Retrieved from: https://provea.org/actualidad/derechos-civiles-y-politicos/ derecho-a-la-vida/lupa-por-la-vida-policias-y-militares-asesinaron-a-2853-personas-en-venezuela-durante-2020-4/

Puente Camba, José Manuel and Jesús Adrián Rodríguez. 2020. Venezuela En Etapa De Colapso macroeconómico: Un análisis histórico Y Comparativo. América Latina Hoy 85(julio): 55-72.

Puerta, María Isabel. 2021, January 15. "Magazuelans: How Venezuelan Americans Embraced Trump as Their Savior". NACLA. Retrieved from: https://nacla.org/venezuelan-american-trump-voters

Ramsey, Geoff and David Smilde. 2020. "Recalibrating U.S. Policy in Venezuela: Learning from Failure and Seizing Opportunities". WOLA. Retrieved from: https://www. wola.org/wp-content/uploads / 2021/01/Recalibrating-U.S.-policy-in-Venezuela.-Ramsey.-Smilde.-Dec.-2020.pdf

Reuters. 2020, December. New buyers spur a near doubling in Venezuela oil exports in November: data, Reuters, Retrieved from: https://www.reuters.com/article/us-venezuela-oil-exports-idUSKBN28C2VE

Robinson, Neil. 2011. Russian Patrimonial Capitalism and the International Financial Crisis, Journal of Communist Studies and Transition Politics, 27:3-4, 434-455.

Rodríguez Rosas, Ronny. 2020, May 11. “Guaidó acepta renuncia de J.J. Rendón y Sergio Vergara". Efecto Cocuyo. Retrieved from: https:/ / efectococuyo.com/politica/guaidoacepta-renuncia-de-j-j-rendon-y-sergio-vergara-al-centro-de-gobierno/

Rodríguez, Francisco. 2019. "Sanctions and the Venezuelan economy: What the data say. Latam Economics Viewpoints". Retrieved from: https://torinocap.com/wp-content/ uploads/2019/06/Sanctions-and-Vzlan-Economy-June-2019.pdf

Rosales, Antulio. 2018. "China and the decaying of socialist rentierism in Venezuela: instability and the prevalence of non-interventionism". Third World Thematics: A TWQ Journal 3:4: 552-568.

Rosales, Antulio. 2019. "Radical rentierism: gold mining, cryptocurrency and commodity collateralization in Venezuela". Review of International Political Economy 26(6): 1311-1332. 
Rosati, Andy, Alex Vasquez and Jennifer Surane. 2020, November 11. "Zelle has turned dollar-starved Venezuela into a cashless test lab". Bloomberg. Retrieved from: https:/ / www.bloomberg.com/news / features/2020-11-11/zelle-has-turned-dollar-starvedvenezuela-into-a-cashless-test-lab

Rutland, Peter. 2013. "Neoliberalism and the Russian transition". Review of International Political Economy 20(2): 332-362.

Salmerón, Victor. 2020, September. ¿Cómo avanza la dolarización en Venezuela? Prodavinci, Retrieved from: https://prodavinci.com/como-avanza-la-dolarizacion-en-venezuela/

Selçuk, Orcun and Dilara Hekimci. 2020. "The rise of the democracy - authoritarianism cleavage and opposition coordination in Turkey (2014-2019)". Democratization 27(8): 1496-1514.

Seijas Meneces, Carlos. 2021, January. "A la calladita el chavismo reprivatiza empresas que expropió y llevó a la quiebra." Tal Cual. Retrieved from https://talcualdigital. com/a-la-calladita-el-chavismo-reprivatiza-empresas-que-expropio-y-llevo-al-colapso/

Stallings Barbara and Wilson Peres. 2011. "Is Economic Reform Dead in Latin America? Rhetoric and Reality since 2000". Journal of Latin American Studies 43(4): 755-786.

Sucre, Ricardo. 2021, March 1. "Claves de la encerrona de la oposición en Bogotá". El Cooperante. Retrieved from https://elcooperante.com/claves-de-la-encerrona-de-la-oposicion-en-bogota/

Sutherland, Manuel. 2019. ¿Una dolarización «antiimperialista»? Nueva Sociedad. Retrieved from: https://www.nuso.org/articulo/venezuela-Maduro-dolarizacion/

Tal Cual. 2020, May 10. Michael Penfold: A la oposición no la ayuda creerse gobierno sin controlar el territorio. Retrieved from: https://talcualdigital.com/michael-penfolda-la-oposicion-no-la-ayuda-creerse-gobierno-sin-control-del-territorio/

Tomillo, Manuel. 2020, November 22. "Datanálisis: Más del 62 \% de los venezolanos no está ni con Guaidó ni con Maduro". Efecto Cocuyo. https://efectococuyo.com/politica/ datanalisis-mas-del-62-de-los-venezolanos-no-esta- ni-con-guaido-ni-con-maduro/.

Trak, Juan Manuel. 2020. "Venezuela: Changes and continuities in post-Chavez era". In Political Representation in Southern Europe and Latin America: Before and After the Great Recession and the Commodity Crisis, edited by André Freire, Mélany Barragán, Xavier Coller, Marco Lisi and Emmanouil Tsatsanis. London: Routledge.

UCAB. 2020. Encuesta Nacional sobre Condiciones de Vida Venezuela 2010. Caracas: Universidad Católica Andrés Bello. Retrieved from: https://insoencovi.ucab.edu.ve/ indicador-pobreza/

UNHRC. 2020. Report of the independent international fact-finding mission on the Bolivarian Republic of Venezuela (A/HRC/45/33). Retrieved from: https://reliefweb.int/sites/reliefweb.int/files/resources/A_HRC_45_33_AUV.pdf

Vasileva, Alexandra. 2018. Trapped in Informality: The Big Role of Small Firms in Russia's Statist-patrimonial Capitalism. New Political Economy 23(3): 314-330.

WOLA. 2021, March 16. "Breaking the Stalemate: How Venezuelan Civil Society is Pushing for Free and Fair Elections". Retrieved from: https://www.youtube.com/watch?$\mathrm{v}=$ PetNyF8NB_o\&ab_channel=WOLA\%3AWashingtonOfficeonLatinAmerica

Yapur, Nicole. 2021, January 2. "Venezuela's Maduro plans shift to a fully digitalized economy". Bloomberg. Retrieved from: https://www.bloomberg.com/news/articles/2021-01-02/venezuela-s-maduro-plans-shift-to-a-fully-digitalized-economy

Received: April 1, 2021

Accepted: July 15, 2021 
Antulio Rosales is an Assistant Professor in the Department of Political Science at the University of New Brunswick. He obtained his PhD in Global Governance from the University of Waterloo and the Balsillie School of International Affairs; he was a post-doctoral fellow at the Centre for Development and the Environment of the University of Oslo. Antulio's research deals with issues of political economy and development in South America, particularly focusing on resource extraction. His publications have appeared in international political economy, comparative politics, and international relations journals such as Review of International Political Economy, Globalizations, International Studies Quarterly, Resources Policy and Third World Quarterly. Email: arosales@unb.ca

Maryhen Jiménez is a Postdoctoral Research Associate at the Latin American Centre at the University of Oxford. She obtained her PhD in Politics from the University of Oxford in 2020. Her dissertation received the 2021 PSA Lord Bryce Prize for best dissertation in comparative politics. She holds an MPhil in Latin American Studies from Oxford (distinction) and a BA in Political Science from the Goethe University Frankfurt (distinction) and has been an academic visitor at Princeton University and CIDE (Mexico). Her research spans the fields of comparative authoritarianism, democratization, opposition movements and political parties and has been published at Political Studies. Email: maryhen.jimenezmorales@area.ox.ac.uk 
